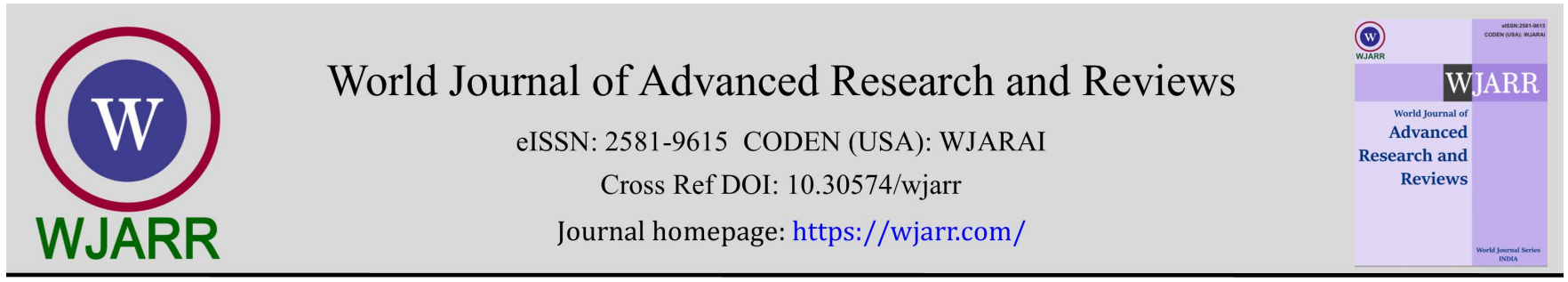

(RESEARCh ARTICLE)

\title{
Study of the antibacterial capacity of extracts of Solanum incanum L., (Solanaceae) traditionally used for the management of avian cholera in rural areas of Burkina Faso
}

\author{
Modou Séré 1, ${ }^{*}$, Kiessoun Konaté 2,3, Balamoussa Santara 3,4, Dominique O. Sanou 3, 4 and Adrien M.G. Belem 5 \\ ${ }^{1}$ Institute of Environmental Sciences and Rural Development, University of Dedougou, P.O. Box 176, Dedougou, Burkina \\ Faso. \\ 2 Laboratory of Biochemistry, Biotechnology, Food Technology and Nutrition, Department of Biochemistry and \\ Microbiology, University Joseph Ki-ZERBO, 03 P.O. Box: 848, Ouagadougou 03, Burkina Faso. \\ ${ }^{3}$ Applied Sciences and Technologies Training and Research Unit, University of Dedougou, P.O. Box 176, Dedougou, Burkina \\ Faso. \\ ${ }^{4}$ Sciences and Technologies Training and Research Unit, University of Nazi BONI, 01 BP 1091 Bobo- Dioulasso 01, Burkina \\ Faso. \\ 5 Institute of Rural Development, University of Nazi BONI, 01 BP 1091 Bobo- Dioulasso 01, Burkina Faso.
}

World Journal of Advanced Research and Reviews, 2022, 13(01), 047-057

Publication history: Received on 05 November 2021; revised on 23 December 2021; accepted on 25 December 2021

Article DOI: https://doi.org/10.30574/wjarr.2022.13.1.0717

\begin{abstract}
Nowadays, thanks to the rise of microbial resistance, the lack of health care personnel and especially the high cost of synthetic molecules, phytotherapy could be a panacea in many developing countries. For this reason, the present work which aims to evaluate the phenolic compounds and to study the antibacterial capacity of extracts of roots, stems, leaves and fruits of Solanum incanum L., (Solanaceae) traditionally used for the treatment of pasteurellosis or avian cholera in Burkina Faso, was undertaken. For this purpose, we collected plant material in the commune of Dedougou. After extraction with acetone and water, colorimetric tests were carried out on the different extracts and revealed mostly the presence of tannins and coumarins. The Hydroacetone macerated extract was found to be very interesting for biological activities compared to the macerated extracts and the aqueous decoctions. Inhibition of bacterial growth on different bacterial strains was also shown for all the extracts, especially with Hydroacetone extract. These results could be mainly explained by the inhibitory effect of phenolic compounds. The Hydroacetone extract was also found to be especially very relevant for the prevention and treatment of microbial diseases from poultry.
\end{abstract}

Keywords: Solanum incanum; Phenolic compounds; Antibacterial activity; Pasteurelloses

\section{Introduction}

Burkina Faso is an agro-sylvo-pastoral country where livestock farming employs nearly $86 \%$ of the country's active population and represents about 10 to $20 \%$ of the country's gross domestic product (GDP). The livestock sector is the second largest contributor to agricultural value added, after cotton, whose poultry sector alone accounts for $6 \%$ of value added [1]. The country produces over 44 million head of poultry. Poultry provides livelihoods to about 1.6 million households and its positive contribution has been quantified at USD 31.5 million (about 27\% of the sector's GDP) [2].

Today, in an environment marked by climate change, resistance of microorganisms to antibiotics and globalization of the economy, poultry commonly raised in villages (hens and guinea fowl) suffer from devastating diseases such as

\footnotetext{
* Corresponding author: Modou Séré

Institut des Sciences de l’Environnement et du Développement Rural, Université de Dédougou, P.O. Box 176, Dedougou, Burkina Faso.

Copyright $(2022$ Author(s) retain the copyright of this article. This article is published under the terms of the Creative Commons Attribution Liscense 4.0.
} 
pasteurellosis that strongly affect growth and production [3]. Poultry can thus have adverse effects on public health due to zoonotic diseases such as pasteurellosis [1,2].

Pasteurellosis, also known as fowl cholera, is in fact an infection caused by the bacterium Pasteurella multocida (P. multocida) which is a Gram-negative, immobile, capsulated, extracellular bacterium [4]. It affects all avian species and there are many healthy carriers in wild birds [5]. Virulent materials include secretions, droppings, eggs and especially cadavers where the bacterium multiplies readily. The transmission of $P$. multocida is horizontal, indirect but mostly direct $[5,6,7,8$, and 9]. There does not appear to be vertical transmission. The route of entry of the bacterium is mainly aerial, but oral, conjunctival and cutaneous routes are possible [10].

Moreover, the treatment of pasteurellosis is effective in acute forms if it is quickly implemented, but it is disappointing in chronic forms and too late in superacute forms. It is treated by antibiotic therapy based on an antibiogram, associated with vitamins (A, B and C). Synthetic products such as quinolones, cephalosporins and tetracyclines are mainly used [10]. However, due to the high cost of synthetic products and their ineffectiveness and unavailability, some farmers resort to traditional medicine which is very relevant in the management of infectious diseases [11, 12 and 13].

It is in this context some medicinal plants are used in the Boucle of Mouhoun region to treat pasteurellosis in village poultry farming. Indeed, the production of phyto-medicine often requires the composition of two or more plants [14 and 15]. One production involves the combination of the leafy stems, leaves and fruits of Solanum incanum. This combination is prepared with water some of which are used to bathe poultry and wash the barnyard while some are drunk by the poultry. This combination, claimed by the traditional poultry farmer, ensures the management of bird flu in village poultry farms within one to two weeks. But no study to our knowledge has reported on the antioxidant and antibacterial properties of polyphenol-rich bark extracts in the management of salmonellosis in traditional poultry farming. The lack of scientific data to support these claims prompted this study to evaluate the potential antioxidant and antibacterial properties of polyphenol-rich fractions of the bark of this plant in bacterial models to provide a scientific basis for the traditional use of this plant for improved management of salmonellosis. More specifically, we will determine the major molecular families through phytochemical screening and evaluate the biological activity of these extracts.

\section{Material and methods}

\subsection{Study site}

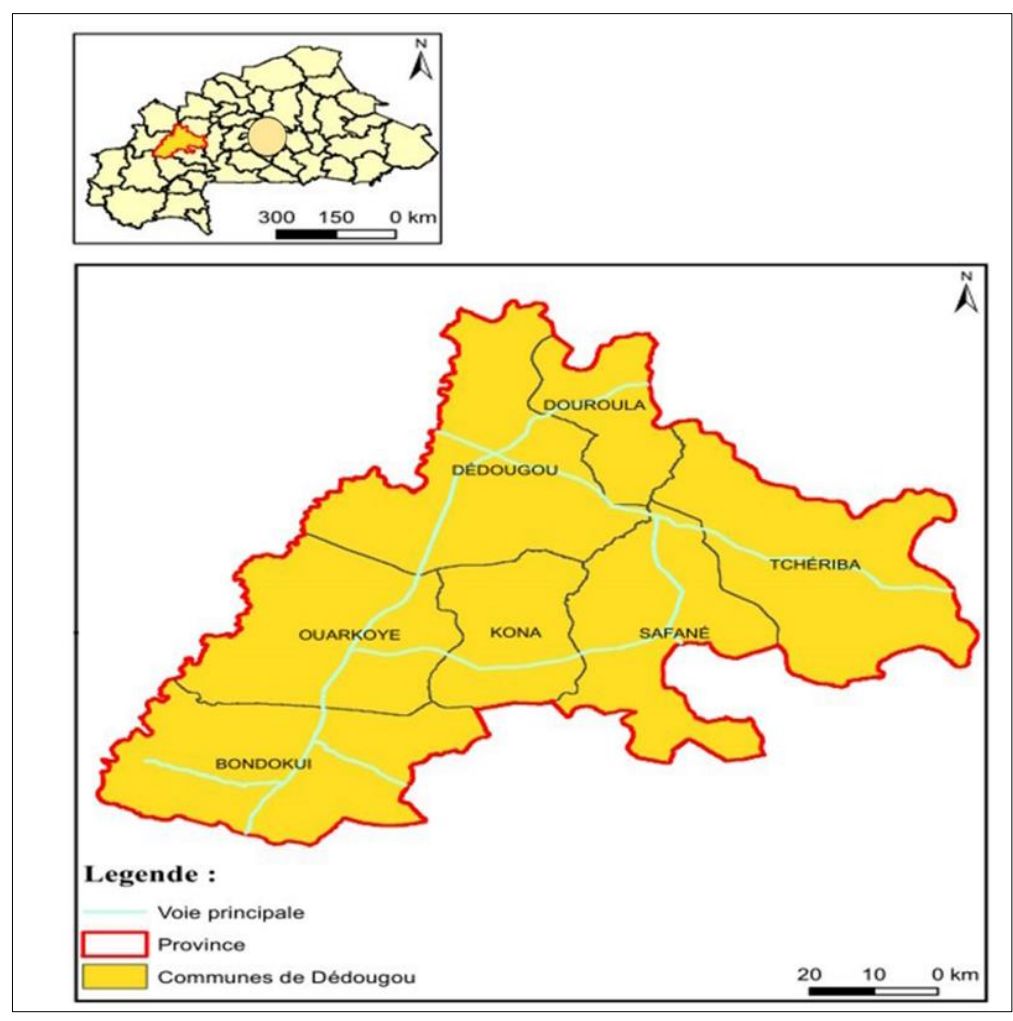

Figure 1 Map of the study area (Santara, 2020) 
Our study was carried out in Dedougou in the Boucle of Mouhoun Region (Figure 1). Indeed, this region is located in the North-West of Burkina Faso with an area of $34497 \mathrm{~km}^{2}$ and with Dedougou as its capital. Between longitudes $-2.4 \mathrm{E}$ and -4.60 and latitudes $11.23 \mathrm{~N} 0$ and $13.70 \mathrm{~S}$, it is bounded to the East by the Centre-West region, to the North and West by the Republic of Mali over nearly 437 Kilometers of border, to the North-East by the North region, to the South by the Hauts-Bassins and South-West regions [16].

\subsection{Plant material}

\subsubsection{Collection and identification of plant material}

Leafy stems, leaves and fruits of Solanum incanum (Solanaceae) were collected in Dedougou, in the month of February 2016. It was recognized by its local name and then taxonomically identified and confirmed by a Professeur plant taxonomist Millogo Rasolodimby of Plant Sciences Department, University of Ouagadougou. All samples were collected in the morning at $7 \mathrm{am}$. They were air-dried $(23 \pm 2 \circ \mathrm{C})$ for two weeks before powdered using grinder Retsch type SM 2000/1430/Upm/Smf, Haan, Germany.

\subsection{Microbiological material}

The microbiological material consisted of ATCC (American Type Culture Collection) bacterial strains from Grenoble Cedex 2, France: Pasteurella multocida ATCC 11039, Pasteurella multocida subsp. Multocida ATCC 43137 and 12947, Pasteurella haemolytica ATCC 33396, Pasteurella multocida subsp. Gallicida ATCC 51689, Pasteurella multocida subsp Septica ATCC 51688, Pasteurella stomatis ATCC 43327, Pasteurella dagmatis ATCC 43325, Pasteurella canis ATCC 43326, Pasteurella testudinis ATCC 33688. And, on the other hand, wild strains of gastroenteritis in poultry from the LNE (Laboratoire National d'Elevage) such as: Pasteurella multocida, haemolytica and gallinarum. These strains were identified according to the protocol of the Medical Bacteriology Manual (11).

\subsection{Growing media}

We used Muller Hinton Agar medium (B D DIFCO, USA) and Muller Hinton Broth medium (DIFCO, USA). These media are specific in that their $\mathrm{pH}$ is neutral; this allows the growth of any microorganism. In addition, the Muller Hinton Agar medium (B D DIFCO, USA) which is specific for antibiograms was.

\subsection{Extractions}

\subsubsection{Maceration}

In a judged $500 \mathrm{~mL}$ flask, we first took $50 \mathrm{~g}$ of powder of leafy stems, leaves and fruits of Solanum incanum. Then, we added $400 \mathrm{~mL}$ of acetone $(80 \%)$ and supplemented with distilled water to the mark. Finally, we centrifuged and macerated with water for 24 hours.

\subsubsection{Total aqueous decoction}

We first weighed $50 \mathrm{~g}$ of powdered plant material of fruits, leaves and leafy stems of solanum incanum. Then we put in flasks containing respectively $500 \mathrm{ml}$ of distilled water after which they were centrifuged. Finally, the decoctates were boiled in $500 \mathrm{ml}$ flasks for $1 \mathrm{~h}$ followed by condensation (BUCCHI Rotavapor R200). The macerates and decocts were freeze-dried in a freeze-dryer (TELSTAR-Cryodos50), then the freeze-dried products were packaged in sterile bottles and stored in a dark place at room temperature. The yields of the extractions were calculated by the following formula:

$$
\mathrm{R}=\frac{\text { Mass of extracted residue }}{\text { Vegetable powder mass }} \times 100
$$

\subsection{Qualitative analysis of phenolic compound}

The different extracts of leafy stems, leaves and fruits of Solanum incanum were subjected to different tests in order to characterize the main groups of secondary metabolites. The methods described by Ciulei [17] were used. These are qualitative methods to identify the chemical groups present in the plant.

\subsubsection{Identification of tannins and polyphenols by the FeCl3 test}

This test was performed on the aqueous and hydroacetone extracts as well as on the hydrolysates of the extracts. We added a few drops of a [1\%] FeCl3 solution to $1 \mathrm{ml}$ of each extract diluted in $2 \mathrm{ml}$ of distilled water. The appearance of a blue-black coloration indicated the presence of gall tannin [17]. 


\subsubsection{Identification of flavonoids by the Shibata test}

This test also was performed on the aqueous and hydroacetone extracts as well as on the hydrolysates of the extracts. Each residue obtained was dissolved in $2 \mathrm{ml}$ of $50^{\circ}$ methanol at warm temperature and transferred to test tubes. Fragments of magnesium turnings and 4-5 drops of hydrochloric acid were added. A red or orange colour indicated the presence of flavonic aglycones [17].

\subsubsection{Identification of coumarins}

We evaporated to dryness $5 \mathrm{ml}$ of each test extract and dissolved the residues by heating in $2 \mathrm{ml}$ of water. After cooling, the resulting solution was divided into 2 test tubes. The first one was used as a control and $0.5 \mathrm{ml}$ of $\mathrm{NH} 4 \mathrm{OH} 10 \%$ was added to the second tube. The appearance of blue or green fluorescence under UV $365 \mathrm{~nm}$ lamp indicates the presence of coumarins [17 and 18].

\subsection{Study of antibacterial activity}

\subsubsection{Preparation of plant extracts for bacterial testing}

For all our tests, we used plant extract solutions of concentration $100 \mathrm{mg} / \mathrm{mL}$. The lyophilisates of the macerated and decocted aqueous extracts were dissolved in distilled water, while those of the hydroacetone macerates were dissolved in DMS010\% (1 mL of DMSO in $9 \mathrm{~mL}$ of sterile distilled water). The extract solutions were sterilized by filtration through $0.22 \mu \mathrm{m}$ millipore filters. In addition, reference antibiogram discs including amoxicillin (10 $\mu \mathrm{g} /$ disc) were used.

\subsubsection{The bacterial inoculum}

An inoculum of $10^{6} \mathrm{CFU} / \mathrm{ml}$ was prepared from bacterial strain dissolved in sterile physiological medium (0.9\% $\left.\mathrm{NaCl}\right)$ and compared with a solution of $0.5 \mathrm{Mac}$ farland. When the two turbidities are identical then the inoculum contains $10^{6}$ $\mathrm{CFU} / \mathrm{ml}[19]$.

\subsubsection{Determination of inhibition diameters or antibiograms}

Diameters were determined according to the method of Rabe and Van-Staden [20], Haidarliu et al. [21] and konaté et al., [22]. We poured $5 \mathrm{ml}$ of Muelle Hinton agar into $53 \mathrm{~mm}$ petri dishes and inoculated with $0.2 \mathrm{ml}$ inoculums using $2 \mathrm{~mL}$ syringes. We used 3 plates for each bacterial strain. The plates containing the agar were then dried in a lighted fume hood. Each $6 \mathrm{~mm}$ diameter sterile Whattmam filter paper disc would be soaked with $10 \mu \mathrm{L}$ of each extract following the cascade dilutions and then placed in each inoculated petri dish. The whole is incubated for 24 hours at $37^{\circ} \mathrm{C}$. The diameters of the inhibition zones were measured.

Extracts with $\geq 3$ zones of inhibition (i.e. $9 \mathrm{~mm}$ ) were considered to have antibacterial activity [21 and 22]. We repeated all tests 3 times.

\subsubsection{Determination of MICs}

MICs (minimum inhibitory concentration) were determined according to the techniques of Eloff [23], Konaté et al. [22] and National Committee for Clinical Laboratory Standards [24]. A 96-well cell culture plate (NUNC, Denmark) was used and in each well $100 \mu \mathrm{L}$ of M.H. broth medium was introduced. For each bacterial strain, 3 columns of 8 wells (decreasing dose $100-0.78125 \mathrm{mg} / \mathrm{mL})$ of the plate were used and each well received medium $(100 \mu \mathrm{L}+$ decreasing dose extract + inoculum $(10 \mu \mathrm{L})$ and INT $(50 \mu \mathrm{L} ; 0.2 \mathrm{mg} / \mathrm{mL}$ for $30 \mathrm{~min})$ respectively. Plates were plated for 18 to 24 hours incubation in a $37^{\circ} \mathrm{C}$ oven with the lowest concentrations that turned red were considered to be the inhibition wells. The MIC wells.

\subsection{Statistical analysis}

The data obtained from the various analyses were statistically processed using R-Studio software in analysis of variance to assess the inhibitory effect of extracts on bacteria. Duncan's multiple comparison test was used to judge the difference between the means of the treatments at $5 \%$ probability level.

\section{Results and discussion}

\subsection{Extraction yields}

Figure 2 illustrates the yields of extractions of the various extracts. The best yield was obtained with hydroacetone macerate followed by aqueous decoction and aqueous macerate. This would mean that acetone is a good solvent for 
extraction. Among the types of extracts, the combination of Leafy stems + Fruits + Leaves gives very relevant results compared to other extracts. A comparison of the different types of extracts reveals a significant difference at the $5 \%$ threshold between the extraction yields of Stems + Leaves and the other extracts. This could be explained certainly by the fact that the leaves of Solanum incanum L contain essential oils, which gives a sticky aspect to the extract, with enough losses.

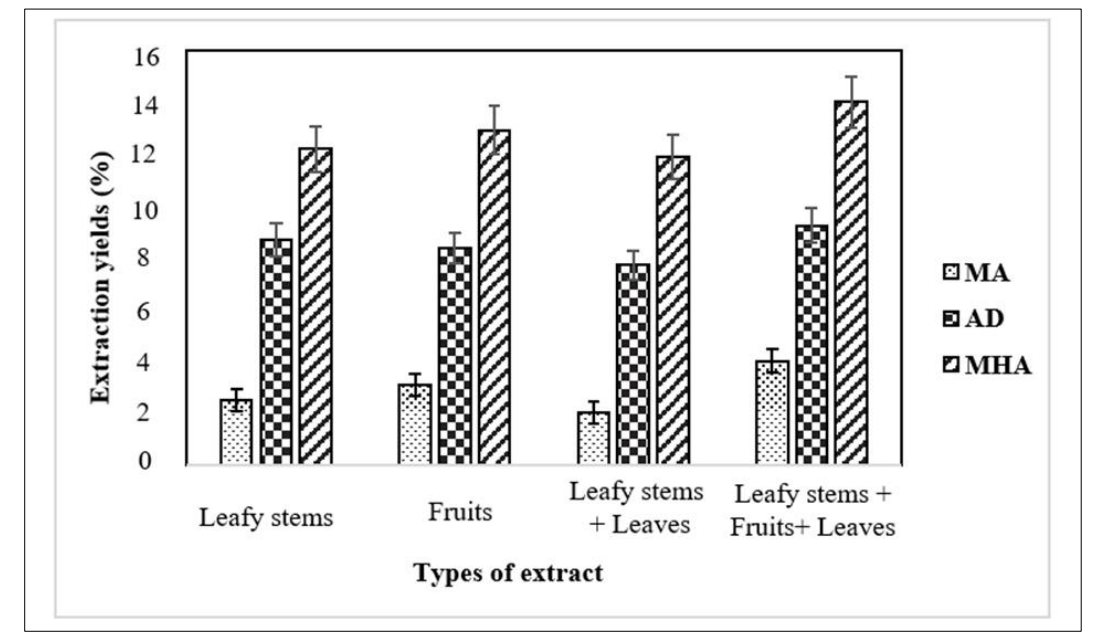

These yields were determined from the Aqueous Macerated (AM), Hydroacetone Macerated (HAM) and Aqueous Decocted (AD) extracts

Figure 2 Extraction efficiency of the differents extract

\subsection{Phenolic compounds of the extracts}

Table 1 Results of characterization tests on Solanum incanum extracts

\begin{tabular}{|c|c|c|c|c|}
\hline & Sought-after compound & MA & MHA & DA \\
\hline \multirow{3}{*}{ Leafy stems extracts } & Tannins & + & + & + \\
\hline & Flavonoids & - & + & - \\
\hline & Coumarins & + & + & + \\
\hline \multirow{3}{*}{ Leaves extracts } & Tannins & + & ++ & + \\
\hline & Flavonoids & - & + & - \\
\hline & Coumarins & + & ++ & + \\
\hline \multirow{3}{*}{ Fruits extracts } & Tannins & + & ++ & + \\
\hline & Flavonoids & - & + & - \\
\hline & Coumarins & + & + & + \\
\hline \multirow{3}{*}{ Combination of extracts (Leafy stems + leaves + fruits) } & Tannins & + & ++ & ++ \\
\hline & Flavonoids & - & ++ & + \\
\hline & Coumarins & ++ & ++ & ++ \\
\hline
\end{tabular}


Table 2 Results of inhibition diameters and MICs with ATCC reference strains with Leafy stems extracts

\begin{tabular}{|c|c|c|c|c|c|c|c|c|c|c|c|c|}
\hline Activities & $\begin{array}{l}\text { Excerpts/ } \\
\text { Antibi }\end{array}$ & P.m. 11039 & P.m. 43137 & P.h.33396 & P.g.51689 & P.s.51688 & P.m.12947 & P.s. 43327 & P.d. 43325 & P.c. 43326 & P.t.33688 & $\operatorname{Pr}>\mathbf{F}$ \\
\hline \multirow{4}{*}{ I.D. (mm) } & MA & $11.92 \pm 1.62^{\mathrm{bcde}}$ & $10.22 \pm 0.54 \mathrm{e}$ & $13.63 \pm 1.10^{\mathrm{abc}}$ & c $14.17 \pm 1.31^{\mathrm{ab}}$ & $10.81 \pm 1.10^{\mathrm{de}}$ & $12.24 \pm 0.5$ abcde & $11.44 \pm 1.31^{\text {cde }}$ & $13.21 \pm 0.58 \mathrm{abc}$ & $14.22 \pm 1.01^{\mathrm{a}}$ & $12.66 \pm 0.54 \mathrm{abc}$ & 0.004 \\
\hline & DA & $14.21 \pm 1.01^{\mathrm{bcd}}$ & $13.01 \pm 0.58 \mathrm{~d}$ & $16.18 \pm 1.10 \mathrm{a}$ & $16.56 \pm 1.54^{a}$ & $13.01 \pm 1.01^{\mathrm{d}}$ & $15.01 \pm 0.5^{\mathrm{abc}}$ & $14.02 \pm 1.01^{\mathrm{cd}}$ & $16.18 \pm 1.62^{\mathrm{a}}$ & $16.01 \pm 1.10^{\mathrm{ab}}$ & $16.02 \pm 0.58^{a}$ & 0.005 \\
\hline & MHA & $16.43 \pm 1.1^{\mathrm{cd}}$ & $16.31 \pm 0.10^{\mathrm{cd}}$ & $20.62 \pm 0.54 a$ & $21.01 \pm 1.1^{\mathrm{a}}$ & $15.23 \pm 0.54^{d}$ & $19.32 \pm 0.3^{b}$ & $17.31 \pm 1.1^{\mathrm{c}}$ & $20.02 \pm 0.31^{\mathrm{ab}}$ & $21.22 \pm 0.54^{a}$ & $20.22 \pm 1.10^{a}$ & $<0.0001$ \\
\hline & Amoxicillin & 45 & $>53$ & $>53$ & $>53$ & 40 & 47 & 39 & 48 & $>53$ & $>53$ & \\
\hline \multirow{3}{*}{$\begin{array}{l}\mathrm{CMI} \\
(\mathrm{mg} / \mathrm{ml})\end{array}$} & MA & 25 & 25 & 12.5 & 12.5 & 25 & 12.5 & 25 & 12.5 & 12.5 & 12.5 & \\
\hline & DA & 12.5 & 12.5 & 6.25 & 6.25 & 12.5 & 6.25 & 12.5 & 6.25 & 6.25 & 6.25 & \\
\hline & MHA & 6.25 & 6.25 & 3.125 & 3.125 & 6.25 & 3.125 & 6.25 & 3.125 & 3.125 & 3.125 & \\
\hline
\end{tabular}

P.m.: Pasteurella multocida ATCC 11039; P.m.: Pasteurella multocida subsp. multocida ATCC 43137 and 12947; P.h.: Pasteurella haemolytica ATCC $33396 ;$ P.g. : Pasteurella multocida subsp. gallicida ATCC 51689; P.s. Pasteurella multocida subsp. septica ATCC 51688; P.s.: Pasteurella stomatis ATCC 43327; P.d. Pasteurella dagmatis ATCC 43325; P.c. : Pasteurella canis ATCC 43326; P.t. Pasteurella testudinis ATCC 33688. Values with the same exponential letters are statistically identical while those with different letters are statically different.

Table 3 Results of inhibition diameters and MICs with ATCC reference strains with leafy Leaves

\begin{tabular}{|c|c|c|c|c|c|c|c|c|c|c|c|c|}
\hline Activities & $\begin{array}{l}\text { Extracts/ } \\
\text { Antibio }\end{array}$ & P.m. 11039 & P.m. 43137 & P.h.33396 & P.g.51689 & P.s.51688 & P.m.12947 & P.s. 43327 & P.d. 43325 & P.c. 43326 & P.t.33688 & $\operatorname{Pr}>F$ \\
\hline \multirow{4}{*}{ D.I. (mm) } & MA & $13.63 \pm 0.10^{\mathrm{bc}}$ & $12.52 \pm 0.54^{\mathrm{cd}}$ & $14.31 \pm 1.10^{\mathrm{ab}}$ & $15.02 \pm 0.54^{\mathrm{a}}$ & $12.02 \pm 1.10^{\mathrm{d}}$ & $14.48 \pm 0.58^{\mathrm{ab}}$ & $13.29 \pm 1.10^{\text {bcd }}$ & $15.53 \pm 0.54^{a}$ & $15.26 \pm 1.01^{\mathrm{a}}$ & $14.68 \pm 0.58^{\mathrm{ab}}$ & 0.001 \\
\hline & DA & $16.31 \pm 1.62^{\mathrm{abcd}}$ & $15.79 \pm 0.31^{\mathrm{bcd}}$ & $18.01 \pm 1.01^{\mathrm{ab}}$ & $15.98 \pm 0.54^{\mathrm{abcd}}$ & $15.35 \pm 1.10^{\mathrm{cd}}$ & $16.21 \pm 1.10^{\mathrm{abcd}}$ & $14.78 \pm 0.54^{\mathrm{d}}$ & $17.02 \pm 1.62^{\mathrm{abcd}}$ & $17.52 \pm 1.01^{\mathrm{abc}}$ & $17.12 \pm 1.01^{\mathrm{abv}}$ & 0.056 \\
\hline & MHA & $19.22 \pm 1.10^{\mathrm{de}}$ & $18.21 \pm 1 / 0^{\mathrm{e}}$ & $20.96 \pm 0.54^{\text {bc }}$ & $21.63 \pm 1.10^{\mathrm{abc}}$ & $18.12 \pm 0.58^{\mathrm{e}}$ & $20.63 \pm 1.01^{\mathrm{cd}}$ & $18.63 \pm 1.01 \mathrm{e}$ & $22.31 \pm 0.58^{\mathrm{ab}}$ & $22.43 \pm 0.54^{\mathrm{ab}}$ & $22.18 \pm 1.10^{\mathrm{abc}}$ & $<0.0001$ \\
\hline & Amoxicillin & 45 & $>53$ & $>53$ & $>53$ & 40 & 47 & 39 & 48 & $>53$ & $>53$ & \\
\hline \multirow{3}{*}{$\begin{array}{l}\text { CMI } \\
(\mathrm{mg} / \mathrm{ml})\end{array}$} & MA & 12.5 & 12.5 & 12.5 & 12.5 & 12.5 & 12,5 & 12.5 & 12.5 & 12.5 & 12.5 & \\
\hline & DA & 12.5 & 12.5 & 6.25 & 6.25 & 6.25 & 6.25 & 6.25 & 6.25 & 6.25 & 6.25 & \\
\hline & MHA & 6.25 & 6.25 & 3.125 & 3.125 & 6.25 & 3,125 & 6.25 & 3.125 & 3.125 & 3.125 & \\
\hline
\end{tabular}

P.m.: Pasteurella multocida ATCC 11039; P.m.: Pasteurella multocida subsp. multocida ATCC 43137 and 12947; P.h. : Pasteurella haemolytica ATCC $33396 ;$ P.g. : Pasteurella multocida subsp. gallicida ATCC 51689; P.s. Pasteurella multocida subsp. septica ATCC 51688; P.s.: Pasteurella stomatis ATCC 43327; P.d. : Pasteurella dagmatis ATCC 43325; P.c. : Pasteurella canis ATCC 43326; P.t. Pasteurella testudinis ATCC 33688. Values with the same exponential letters are statistically identical while those with different letters are statically different. 
Table 4 Results of inhibition diameters and MICs with ATCC reference strains with fruit extracts

\begin{tabular}{|c|c|c|c|c|c|c|c|c|c|c|c|c|}
\hline Activities & $\begin{array}{l}\text { Extracts/ } \\
\text { Antibio }\end{array}$ & P.m. 11039 & P.m. 43137 & P.h.33396 & P.g.51689 & P.s.51688 & P.m.12947 & P.s. 43327 & P.d. 43325 & P.c. 43326 & P.t.33688 & $P r>F$ \\
\hline \multirow{4}{*}{ I.D.(mm) } & MA & $13.87 \pm 0.58^{\mathrm{ab}}$ & $12.31 \pm 0.58^{a b}$ & $14.69 \pm 0.10^{\mathrm{ab}}$ & $\mathrm{b} 15.23 \pm 0.54^{\mathrm{ab}}$ & $11.73 \pm 1.01^{b}$ & $14.31 \pm 0.58^{\mathrm{ab}}$ & $12.51 \pm 1.10^{\mathrm{b}}$ & $15.32 \pm 0.54^{\mathrm{a}}$ & $15.43 \pm 1.10^{\mathrm{a}}$ & $14.18 \pm 0.54^{\mathrm{ab}}$ & 0.313 \\
\hline & DA & $17.15 \pm 1.10^{\mathrm{a}}$ & $15.11 \pm 0.54^{c}$ & $17.24 \pm 0.10^{\mathrm{a}}$ & $16.86 \pm 0.58^{\mathrm{ab}}$ & $15.41 \pm 1.10^{\mathrm{bc}}$ & $17.42 \pm 0.54^{\mathrm{a}}$ & $14.72 \pm 0.54^{c}$ & $16.83 \pm 1.62^{\mathrm{ab}}$ & $17.12 \pm 1.01^{\mathrm{a}}$ & $17.72 \pm 0.58^{\mathrm{a}}$ & 0.009 \\
\hline & MHA & $18.35 \pm 0.10^{c}$ & $18.37 \pm 1.10^{c}$ & $21.69 \pm 0.58^{\mathrm{ab}}$ & $22.17 \pm 1.10^{\mathrm{ab}}$ & $17.22 \pm 0.54^{c}$ & $21.26 \pm 0.54^{b}$ & $18.22 \pm 1.10^{c}$ & $21.42 \pm 1.10^{\mathrm{b}}$ & $22.08 \pm 0.58^{\mathrm{ab}}$ & $22.36 \pm 1.10^{\mathrm{ab}}$ & $<0.0001$ \\
\hline & Amoxicillin & 45 & $>53$ & $>53$ & $>53$ & 40 & 47 & 39 & 48 & $>53$ & $>53$ & \\
\hline \multirow{3}{*}{$\mid \begin{array}{l}\text { CMI } \\
\text { (mg/ml) }\end{array}$} & MA & 12.5 & 12.5 & 12.5 & 12.5 & 12.5 & 12.5 & 12.5 & 12.5 & 12.5 & 12.5 & \\
\hline & DA & 12.5 & 12.5 & 6.25 & 6.25 & 6.25 & 6.25 & 6.25 & 6.25 & 6.25 & 6.25 & \\
\hline & MHA & 6.25 & 6.25 & 3.125 & 3.125 & 3.125 & 3.125 & 3.125 & 3.125 & 3.125 & 3.125 & \\
\hline
\end{tabular}

P.m.: Pasteurella multocida ATCC 11039; P.m.: Pasteurella multocida subsp. multocida ATCC 43137 and 12947; P.h. : Pasteurella haemolytica ATCC $33396 ;$ P.g. : Pasteurella multocida subsp. gallicida ATCC

51689; P.s. Pasteurella multocida subsp. septica ATCC 51688; P.s.: Pasteurella stomatis ATCC 43327; P.d. : Pasteurella dagmatis ATCC 43325; P.c. : Pasteurella canis ATCC 43326; P.t. Pasteurella testudinis ATCC 33688. Values with the same exponential letters are statistically identical while those with different letters are statically different.

Table 5 Results of inhibition diameters and MICs with ATCC reference strains with the combination extracts

\begin{tabular}{|c|c|c|c|c|c|c|c|c|c|c|c|c|}
\hline Activities & $\begin{array}{c}\text { Extracts/ } \\
\text { Antibio }\end{array}$ & P.m. 11039 & P.m. 43137 & P.h.33396 & P.g.51689 & P.s.51688 & P.m.12947 & P.s. 43327 & P.d. 43325 & P.c. 43326 & P.t.33688 & $P r>F$ \\
\hline \multirow{4}{*}{ D.I. $(\mathrm{mm})$} & MA & $15.78 \pm 0.10^{\mathrm{ab}}$ & $14.46 \pm 0.58^{\mathrm{bc}}$ & $16.60 \pm 1.10^{\mathrm{a}}$ & $16.32 \pm 0.58^{\mathrm{a}}$ & $13.64 \pm 1.10^{\mathrm{c}}$ & $16.52 \pm 0.58^{a}$ & $14.60 \pm 1.01^{b c}$ & $16.41 \pm 0.58^{a}$ & $16.52 \pm 1.01^{\mathrm{a}}$ & $16.27 \pm 0.54^{\mathrm{ab}}$ & 0.003 \\
\hline & DA & $18.21 \pm 0.54 \mathrm{abc}$ & $17.23 \pm 0.58^{\mathrm{bc}}$ & $19.29 \pm 1.10^{\mathrm{a}}$ & $17.71 \pm 1.01^{\mathrm{abc}}$ & $17.47 \pm 1.01^{b c}$ & $17.33 \pm 0.54 \mathrm{bc}$ & $16.68 \pm 1.01^{c}$ & $17.76 \pm 1.10^{\mathrm{abc}}$ & $18.23 \pm 1.10^{\mathrm{abc}}$ & $18.78 \pm 0.54^{\mathrm{ab}}$ & 0.099 \\
\hline & MHA & $20.31 \pm 1.10^{\mathrm{e}}$ & $20.42 \pm 1.01$ de & $22.63 \pm 1.01^{\mathrm{bc}}$ & $24.22 \pm 1.1^{\mathrm{abc}}$ & $18.29 \pm 0.58^{\mathrm{f}}$ & $23.18 \pm 0.58^{\mathrm{bc}}$ & $22.33 \pm 1.10^{\mathrm{cd}}$ & $22.46 \pm 1.10^{\mathrm{bc}}$ & $24.17 \pm 0.58^{\mathrm{abc}}$ & $24.31 \pm 1.01^{\mathrm{ab}}$ & $<0.0001$ \\
\hline & Amoxicillin & 45 & $>53$ & $>53$ & $>53$ & 40 & 47 & 39 & 48 & $>53$ & $>53$ & \\
\hline \multirow{3}{*}{$\begin{array}{c}\mathrm{CMI} \\
(\mathrm{mg} / \mathrm{ml})\end{array}$} & MA & 6.25 & 6.25 & 6.25 & 6.25 & 6.25 & 6.25 & 6.25 & 6.25 & 6.25 & 6.25 & \\
\hline & DA & 6.25 & 6.25 & 3.125 & 3.125 & 3.125 & 3.125 & 3.125 & 3.125 & 3.125 & 3.125 & \\
\hline & MHA & 3.125 & 3.125 & 1.5625 & 1.5625 & 1.5625 & 1.5625 & 1.5625 & 1.5625 & 1.5625 & 1.5625 & \\
\hline
\end{tabular}

P.m.: Pasteurella multocida ATCC 11039; P.m.: Pasteurella multocida subsp. multocida ATCC 43137 and 12947; P.h. : Pasteurella haemolytica ATCC 33396; P.g. : Pasteurella multocida subsp. gallicida ATCC 51689; P.s. Pasteurella multocida subsp. septica ATCC 51688; P.s.: Pasteurella stomatis ATCC 43327; P.d. : Pasteurella dagmatis ATCC 43325; P.c. : Pasteurella canis ATCC 43326; P.t. Pasteurella testudinis ATCC 33688. Values with the same exponential letters are statistically identical while those with different letters are statically different. 
Table 6 Results of wild type strains

\begin{tabular}{|l|l|c|c|c|}
\hline \multirow{2}{*}{ Types of extracts } & \multirow{2}{*}{ Extracts } & \multicolumn{3}{|c|}{ Inhibition diameters (mm) } \\
\cline { 3 - 5 } & & P. multocida & P. haemolytica & P. gallinarum \\
\hline Leafy stems & MA & $9.62 \pm 0.54$ & $10.82 \pm 0.58$ & $12.61 \pm 1.58$ \\
\hline \multirow{2}{*}{ Leaves } & MHA & $10.21 \pm 1.1$ & $11.37 \pm 1.1$ & $14.21 \pm 1.10$ \\
\hline & MA & $12.22 \pm 0.52$ & $12.26 \pm 0.54$ & $13.31 \pm 0.58$ \\
\hline & DA & $13.56 \pm 0.54$ & $14.18 \pm 1.10$ & $14.68 \pm 1.62$ \\
\hline Fruits & MHA & $17.42 \pm 1.10$ & $16.41 \pm 1.10$ & $18.01 \pm 1.31$ \\
\hline & MA & $11.94 \pm 0.52$ & $13.21 \pm 0.54$ & $12.93 \pm 0.54$ \\
\hline & DA & $13.68 \pm 0.54$ & $14.31 \pm 1.10$ & $15.01 \pm 1.01$ \\
\hline Combination & MHA & $17.92 \pm 1.10$ & $17.11 \pm 1.10$ & $17.98 \pm 1.10$ \\
\hline & MA & $13.62 \pm 0.58$ & $15.29 \pm 0.58$ & $14.72 \pm 0.54$ \\
\hline & DA & $15.46 \pm 0.54$ & $16.21 \pm 1.01$ & $16.22 \pm 0.58$ \\
\hline & MHA & $20.41 \pm 1.10$ & $19.32 \pm 0.58$ & $20.22 \pm 1.10$ \\
\hline & Amoxicillin & 24 & 26 & 28 \\
\hline
\end{tabular}

The phenolic compounds investigated in this study were flavonoids, coumarins and tannins. Indeed, Table 1 shows that phenolic compounds represented by tannins and coumarins were identified in all extracts. Flavonoids, on the other hand, could not be detected in all extracts, which could reflect the probable absence of these compounds or that they are in insufficient quantity to be detected by tube tests following the protocols described by Konate et al. [22]. This justifie the presence of these secondary metabolites in almost all extract combinations (Table 1). Moreover, the absence of flavonoids in the aqueous extracts further confirms that water used as an extraction solvent contains less secondary metabolites than acetone. This would mean that acetone is a good solvent that would retain more polar compounds like coumarins, tannins and flavonoids. These phenolic compounds can accumulate and actively participate in the defense of the plant. Their mode of action is related to their antimicrobial power, their participation in the reinforcement of plant cell walls and their capacity to modulate and induce host defense reactions [25, 26, 27].

\subsection{Antibacterial activity}

In relation to the sensitivity test, it is found that the best values of inhibition diameters are obtained respectively by Hydroacetone Macerated extract (HAM), followed by Aqueous Decoctate extract (AD) and finally Aqueous Macerated (AM). Of all these results, the combination extract (roots + leafy stems + fruits) shows the best results, followed by the stem + leafy stem extract, fruits and finally roots. These results are due to the presence of secondary metabolites mostly present in the MHA extract compared to the other types of extracts. This result makes us say again that acetone would be a very good extraction solvent better than water [27].

Furthermore, the results obtained with the Minimum Inhibitory Concentrations (MIC), respect the same logic according to which, the MHA extract would present the best result (Tables 2 to 6).

The results in Table 6 show that all our extracts are effective against wild strains, which justifies the traditional use of the plant in traditional veterinary pharmacopoeia for the treatment of avian pasteurellosis [25].

Compared to wild strains, our extracts are more active on reference strains than amoxicillin. This could be explained by the origin or provenance of the poultry and the resistance phenomena of the bacteria. However, in general, we note that the strains Pasteurella multocida ATCC 11039, Pasteurella multocida subsp. Multocida ATCC 43137, Pasteurella multocida subsp. Septica ATCC 51688 and Pasteurella stomatis ATCC 43327 seem to be less sensitive to the different extracts. This difference in sensitivity would be related to the nature of the bacterial wall, which is thermoresistant [28]. Indeed, it should be noted that gram-negatives have an outer membrane consisting of phospholipids that constitute a 
barrier to apolar compounds on the one hand, while the porins of the plasma membrane constitute an elective barrier to polar substances [22].

\section{Discussion}

Previous studies have been conducted in different parts of the globe to extract natural substances for screening antibacterial activity [29]. Plants produce highly bioactive molecules that allow them to interact with other organisms in their environment. Many of these substances are important in defense against herbivores and contribute to disease resistance [30]. Many researchers have evaluated the bioactivity of plant extracts and isolated constituents against serious infectious organisms [31].

In Africa, for the treatment of many infections, indigenous medicinal plants are often the only means [32]. Infectious diseases caused by multidrug-resistant microorganisms pose a significant clinical problem. Many bacterial strains are resistant to the standard antibiotic (amoxicillin) compared to the polyphenol-rich fractions. It could be said that metabolites have been found to be responsible for the therapeutic activity of plants [33]. This may be due to the presence of coumarins, polyphenolic compounds (tannins, coumarins and flavonoids) which we had then identified in Solanum extracts on one hand and on the other hand by the alcohols, saponosides, steroids, etc. The natural products were found to possess promising antimicrobial activities when applied alone or in combination and the metabolites were found to be responsible for the therapeutic activity of the plants [34]. This aspect is indeed verified by our different results.

Analysis of the data indicates that the tested polyphenol extract showed significant results compared to amoxicillin. Indeed, the antibacterial activity profile of the isolated constituents (polyphenols) in relation to the antibiotic effects shows that the activity depends on the pure form of the constituents. This may be due to the fact that bioactive constituents, such as polyphenol compounds, were responsible for the antimicrobial activity. Indeed, some previous studies have shown that polyphenolic compounds cause inhibition of a wide range of microorganisms. Phenol is well known as a chemical antiseptic [35]. In addition, phenolic and terpene antimicrobial activities are well documented [36]. Polyphenols, such as tannins and flavonoids, have significant antibacterial activity [32]. The antimicrobial activity of flavonoids is due to their ability to complex with extracellular and soluble proteins and to complex with the bacterial cell wall while that of tannins may be related to their ability to inactivate microbial adhesions, enzymes and cell envelope proteins [30]. The inhibitory activity of our extracts could also be explained by the fact that Pasteurela are Gram bacteria. This may be due to its outer membrane and cell wall structure which is permeable [37].

Bacterial resistance to current antibiotics requires further study of isolated constituents to determine their safety and efficacy profile. This highlights the continued interest in laboratory screening of medicinal plants, not only to determine the scientific rationale for their use, but also to discover new active ingredients. African medicinal plants have focused on phenolic compounds, terpenoids or essential oils [38]. Plants have been found to have good antimicrobial activities and some active principles have been isolated. This further confirms the traditional use of this plant in rural Burkina Faso, especially in the commune of Dedougou for the prevention and treatment of pasteurellosis or avian cholera and many other avian diseases.

\section{Conclusion}

This work allowed us to perform extractions from the roots, stems and leaflets of Solanum incanum. The extraction yields showed a predominance of polar compounds with the Hydroacetone macerated extract either compared to those of the aqueous macerated and decocted extracts, thus showing a low rate of apolar compounds.

In tube tests, polyphenols (tannins and coumarins) were found in all extracts. On the other hand, the Hydroacetone extract showed a better antibacterial activity. These results are due to the presence of phenolic compounds such as tannins and coumarins which are found in the majority. From these results, it could be said then that there is a correlation between total phenolics and biological activities.

Beyond the valorization of local resources, this study contributes scientifically to the acceptance of the use of roots, stems and leaves of Solanum incanum in local poultry farming in Burkina Faso by providing knowledge on the production and use of improved traditional medicines responding to the most common pathologies in rural communities.

In perspective, it would be interesting, even judicious, to test the biological activity, i.e. the antibacterial activity in vivo of these extracts. 


\section{Compliance with ethical standards}

\section{Acknowledgments}

The authors thank Professor Millogo Rasolodimby from the Plants Biology Department of the University of Ouagadougou (Burkina Faso) for the botanical identification of our plant study.

\section{Disclosure of conflict of interest}

The authors declare that they have no competing interests.

\section{References}

[1] MRAH (Ministère des ressources animales et halieutiques). Rapport annuel d'activité. Ougadougou, Burkina Faso. 2018.

[2] FAO. Rapport pays - Élevage durable en Afrique 2050 - Burkina Faso. Organisation des Nations Unies pour l'alimentation et l'agriculture (FAO), Rome. 2018 ; p108.

[3] Billaz R, Beauval V, Boyrivent P. Development of village poultry farming in West Africa. Twenty years of experience in Togo, Mali and Senegal: assessment and perspectives. In Agronomes et vétérinaires sans frontiers; 2011.

[4] Nguyen TH, Niwat C, Juan JCM. Antimicrobial resistance in bacterial poultry pathogens: A review. Vet. Sci. 2017.

[5] Curtis PE, Ollerhead GE, Pasteurella multocida infection of cats on poultry farms. The Veterinary Record. 1980; 110(1): 13-14.

[6] Glisson JR. Bacterial respiratory disease of poultry. Poult Sci. 1998; 77(8): 1139-1142.

[7] Christensen JP. , Fowl cholera. In CM Kahn \& S Line (eds), The Merck veterinary manual. 10 edn, Merck \& Co., Inc. 2010; pp. 2425-2426

[8] Saif YM, Fadly AM. Pasteurellosis and other respiratory bacterial infections. Diseases of poultry, Ames, Iowa, Balckwell. 2008; 739.

[9] Sonaiya E, Swan S. L'aviculture familiale - un manuel technique. Organisation des Nations Unies pour l'alimentation et l'agriculture (FAO), Rome. 2004; p140.

[10] Guérin J, Boissieu C. Avian pasteurellosis. 1879; 8-10.

[11] Johann S, Rizzolatti MG, Donnici CL, De-Resende MA, Paulo S. Antifungal properties of plants used in Brazilian traditional medicine against clinically relevant fungal pathogens. Braz J Microbiol. 2007; 38: 11-14.

[12] Omonkhua AA, Onoagbe IO. Effects of Irvingia grandifolia, Urena lobata and Carica papaya on the Oxidative Status of Normal Rabbits. Internet J. Nutr. Wellness. 2008; 6(2).

[13] Tiwari U, Rastogi B, Singh P, Saraf DK Vyas S. Immunomodulatory effects of aqueous extract of Tridax procumbens in experimental animals. J Ethnopharmacol. 2004; 92: 113-119.

[14] Chidozie V, Adoga GI. Toxicological effects of aqueous extract of Anogeissus Leiocarpus Leaf, Carica Papaya Leaf, and Mangifera Indica. Cancer Biology. 2014; 4(4): 26-34.

[15] Ikpme J, Udensi O, Ekkaluo U, Uyoh E, Asuquo B, \& Udoh F. Effect of crude extract of Carica papaya seeds on the reproductive efficiency of mal albino rats. Global J Pure Applied Sci. 2007; 13: 365-368.

[16] INSD (Institut National de la Statistique et de la Démographie). Annuaire statistique des droits humains et du civisme. Ministere de la justice, des droits humains et de la promotion civique, Ouagadougou, Burkina Faso. 2016 ; p121.

[17] Ciulei I. Methodology for Analysis of Vegetable Drugs: Methodology for Analysis of Vegetable Drugs. Ministry of Chemical Industry, Bucharest. 1982; 11-26.

[18] Wagner H, \& Bladt S. "'Plant Drug Analyses', in A Thin Layer Chromatography." Atlas. $1996 ; 38$.

[19] Ezoubeiri A, Gadhi CA, Fdil N, Benharref A, Jana M \& Vanhaelen M. Isolation and antimicrobial activity of two phenolic compounds from Pulicaria odora L. Journal of Ethnopharmacology. 2005; 99(2): 287-292. 
[20] T Van-Staden JR. Antibacterial activity of South African plants used for medicinal purposes. Journal of Ethnopharmacology. 1997; 56(1): 81-87.

[21] Haidarliu S, Shulz D, Ahissar E. A multi-electrode array for combined microiontophoresis and multiple singleunit recordings. Journal of Neuroscience Methods. 1995; 56(2): 125-131.

[22] Konaté K, Hilou A, Mavoungou JF, Lepengué AN, Souza A, Barro N, Nacoulma OG. Antimicrobial activity of polyphenol-rich fractions from Sida Alba L. (Malvaceae) against co-trimoxazol-resistant bacteria strains. Annals of Clinical Microbiology and Antimicrobials. 2012; 11(5).

[23] Eloff JN. A sensitive and quick microplate method to determine the minimal inhibitory concentration of plant extracts for bacteria. Planta Medica. 1998; 64(8): 711-713.

[24] NCCLS (National Committee for Clinical Laboratory Standards). Performance standard for antimicrobial susceptibility testing: eleventh informational supplement. Document National Committee for Clinical Laboratory Standard, Wayne, PA, USA. 2001; M100-S11.

[25] Scalbert A. Antimicrobial properties of tannins. Phytochemistry. 1991; 30: 3875-3883.

[26] Bruneton J. Pharmacognosie, phytochimie, plantes médicinales. 2e edition, Tec et Doc., Lavoisier, Paris. 1993; 915.

[27] Nacoulma OG. Plantes médicinales et Pratiques médicinales traditionnelles au BURKINA. Fac des Sci Tech Univ Ouagadougou. 1996; 320: 1-328.

[28] López P, Sánchez C, Batlle R, Nerín C. Solid- and vapor-phase antimicrobial activities of six essential oils: Susceptibility of selected foodborne bacterial and fungal strains. Journal of Agricultural and Food Chemistry. 2005; 53(17): 6939-6946.

[29] Ravikumar S, Nazar S, Nuralshiefa A, Abideen S. Antibacterial activity of traditional therapeutic coastal medicinal plants against some pathogens. J Environ Biol. 2005; 26: 383-386.

[30] Cowan M. Plants products as antimicrobial agents. Clin Microbiol Rev. 1999; 12: 564-582.

[31] Parekh J, Sumitra C. In vitro Antimicrobial of Extracts of Launaea procumbens Roxb. (Labiateae), Vitis vinifera L. (Vitaceae) and Cyperus rotundus L. (Cyperaceae). Afr J Biomed Res. 2006; 9: 89-93.

[32] Machado TD, Leal ICR, Amaral ACF, Dos-Santos KRN, Da-Siva MG, Kuster R. Antimicrobial ellagitannin of Punica granutumfruits. J Braz Chem Soc. 2002; 13: 606-610.

[33] Shrivastava SM, Kumar S, Chaudhary M. Time-kill curve studies of against Escherichia coli, Staphylococcus aureus, Klebsiella pneumonia and Proteus vulgaris. Res J Med Plant. 2009; 3(3): 116-122.

[34] Jazani NH, Zartoshti M, Shahabi S, Yekta Z, Nateghi S. Evaluation of the synergistic effect of water soluble extracts of green tea (Camellia sinensis) on the activity of ciprofloxacin in urinary isolated E. coli. J Biol Sci. 2007; 7: 15001503.

[35] Abeer M, Haj A, Sanaa O. Anti-microbial Activity of Acacia nilotica Extracts Against Some Bacteria Isolated from Clinical Specimens. Res J Med Plant. 2007; 1 (1): 25-28.

[36] Mullholl TD, Van-SRJ. Isolation and identification of antibacterial compounds from Vernonia colorata leaves. Journal of Ethnopharmacology. 2002; 80(1): 91-94.

[37] Nikaido H. Outer membrane. In Echerichia coli and Salmonella typhimiruim: Cellular and Molecular Bilogy. American Sociatety for Microbiology Press. 1996; 29-47.

[38] Erasto P, Bojase-Moleta G, Majinda R. Antimicrobial and antioxidant flavonoids from the roots wood of Bolusanthus spesiosus. Phytochem. 2004; 65: 875-880. 